\title{
Peculiarities Regarding the Smooth Entrance of the Drill in Cutting When Processing Steel
}

\author{
Raluca DAICU \\ Transilvania University of Brașov, Romania, raluca.daicu@unitbv.ro \\ Valentin DIȚU \\ Transilvania University of Brașov, Romania, vditu@unitbv.ro
}

\begin{abstract}
Metal drilling is one of the most common methods of obtaining cylindrical bores. At the same time, the drill is the cutting tool that cuts in the most difficult conditions and consequently any measure that leads to the improvement of the cutting process is useful. The smooth entrance in the cutting is a way to increase the durability of the drill and consequently specific devices have been developed. One of these devices is shown in this paper and previous research shows the effectiveness of its use in drilling. The analysis of the device shows that it is used for cutting $41 \mathrm{MoC} 11$ and C45 steels with high speed steel drills, which are in a small range of sizes. The active element of the device is identified, a helical spring working for compression, and by calculating the respective axial force of the torque, is determined exactly the range of diameters of the drills that can cut effectively. At the same time is analyzed the way of enlarging the range of drills used with the device for smooth entrance in cutting, by introducing a second spring, concentric with the first, and which works simultaneously with it, thus the device was reengineered.
\end{abstract}

\section{Keywords}

cutting, drilling, cutting tool wear

\section{Introduction}

Machining remains, even today, the most common way to obtain metal parts in machine construction, which justifies research in this field. Even today, research deal extensively with the cutting process, in order to understand the relations and phenomena that occur when the cutting layer passes into the chip $[1,2,3,4]$. In this way it is tried to find the ways that lead to the increase of the quality (improvement of the roughness) of the processed surfaces but especially to the increase of the dimensional and geometric precision. Research in the field of metal cutting also addresses the wear of the cutting tool, this being the main feature of comparison between the various cutting tools [7, 8]. Among the cutting processes, the drill holds an important place because it is the only one that processes bores in full material. As the cutting tool processes in difficult conditions, the quality of the drill must be as homogeneous as possible. Research [6] shows an innovative method of assessing the quality of drills using the electrical current at cutting. At the same time, any research aimed at increasing the durability of the drill is welcome.

The paper [5] presents a way to increase the durability of the drill by entering it smoothly into the cutting and analyzing the effectiveness of the method using the electrical current obtained from drilling $41 \mathrm{MoC} 11$ steel (breaking strength $-950 \mathrm{~N} / \mathrm{mm}^{2}$ ) with a speed steel drill. 30 drills with a diameter of $\emptyset 8 \mathrm{~mm}$, made of high-speed steel, were acquired. The drills were analyzed under a microscope to identify possible defects and were numbered to be easy to identify. Experiments were then performed to measure the electric current at cutting using the installation shown in Figure 1, first without using the smooth entrance in cutting device and then using the smooth entrance in cutting device. The experimental steps were:

- Microscopic view of drills;

- Measurement of electric current at drilling without smooth entrance in cutting;

- Measurement of electric current at drilling with smooth entrance in cutting;

- Comparison of the obtained results. 

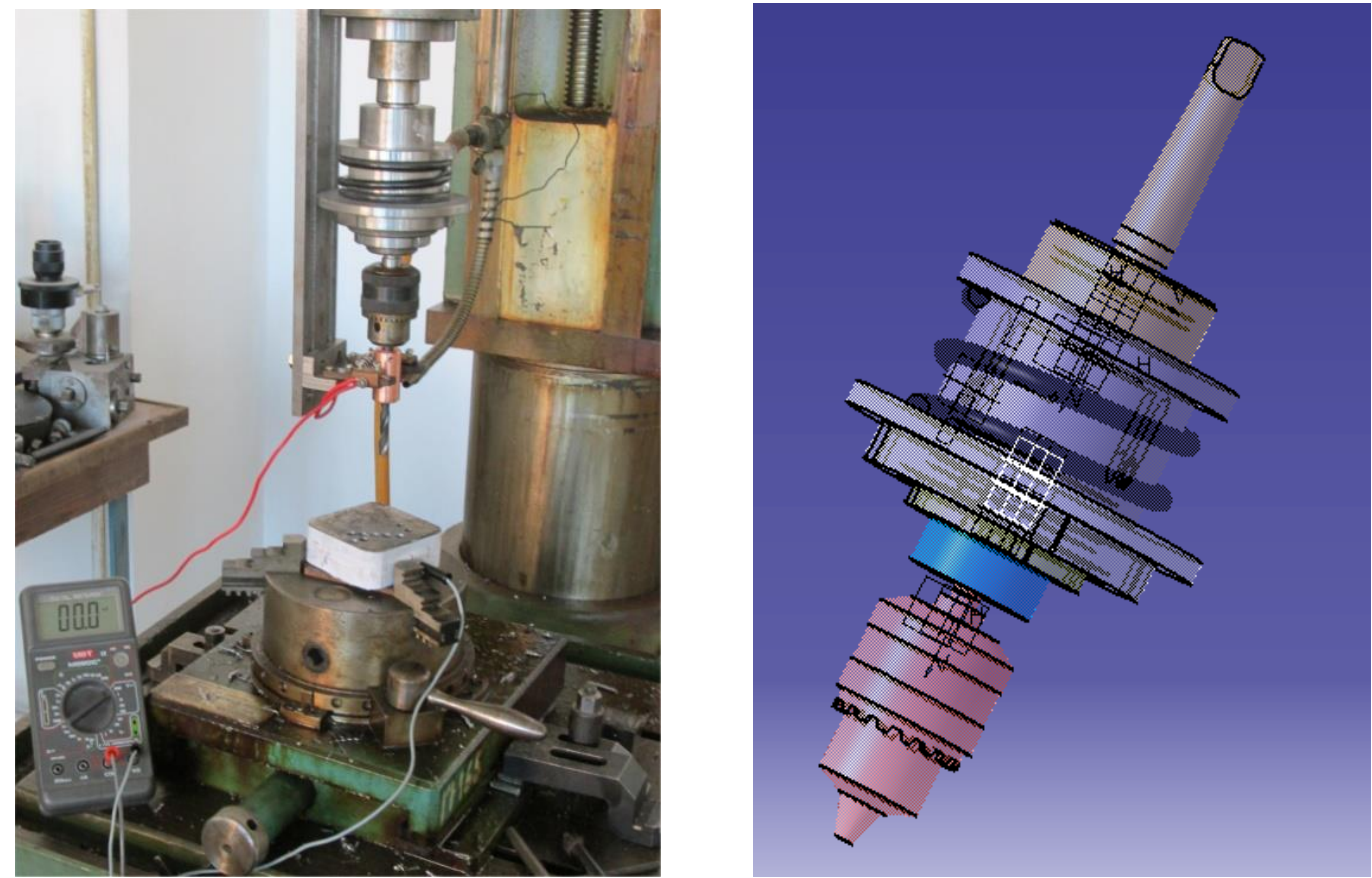

Fig. 1. Installation for measuring the electrical current at drilling with smooth entrance in cutting [5]

Processing was performed with $\mathrm{v}_{\mathrm{c}}=14.07 \mathrm{~m} / \mathrm{min}$ and $\mathrm{f}=0.25 \mathrm{~mm} / \mathrm{rev}$ [5]. At the same time, the axial force at the drilling required to adjust the smooth entrance device was calculated $F_{x}=2560 \mathrm{~N}$ [5].

From the experimental data the charts from Figures 2 and 3 were obtained.



Fig. 2. Variation of the cutting electrical current in the ascending order of the voltage [5]

From the analysis of the two graphs, with very few exceptions, it can be seen that the smooth entrance of the drill in cutting leads to a lower voltage of the electric current and thus to a higher durability of the drill.

Because the drill can enter in cutting smoothly when the axial force at the diameter of the drill core is greater than the prestressing force of the helical spring and when the axial force at the outer diameter is less than the clamping force of the helical spring, it is necessary to determine the diameter range which can be used on the device for smooth entry into the cutting as well as the cutting conditions. 


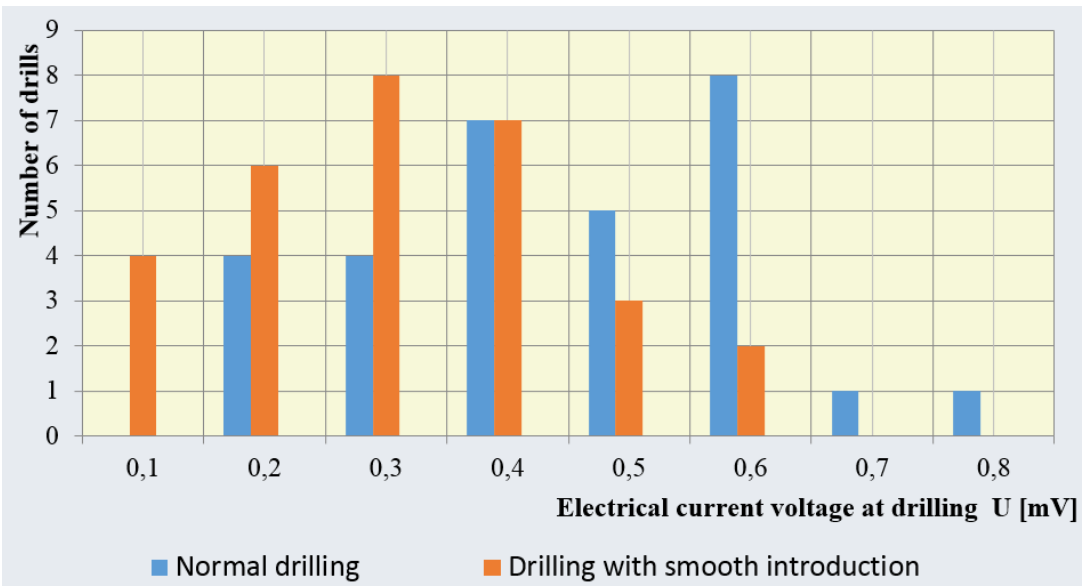

Fig. 3. Variation of the number of drills at the same value of the cutting current [5]

\section{Identification of the Operating Parameters of the Device for a Smooth Entrance of the Drill in Cutting}

The components of the smooth entrance in cutting device are shown in Figure 4.

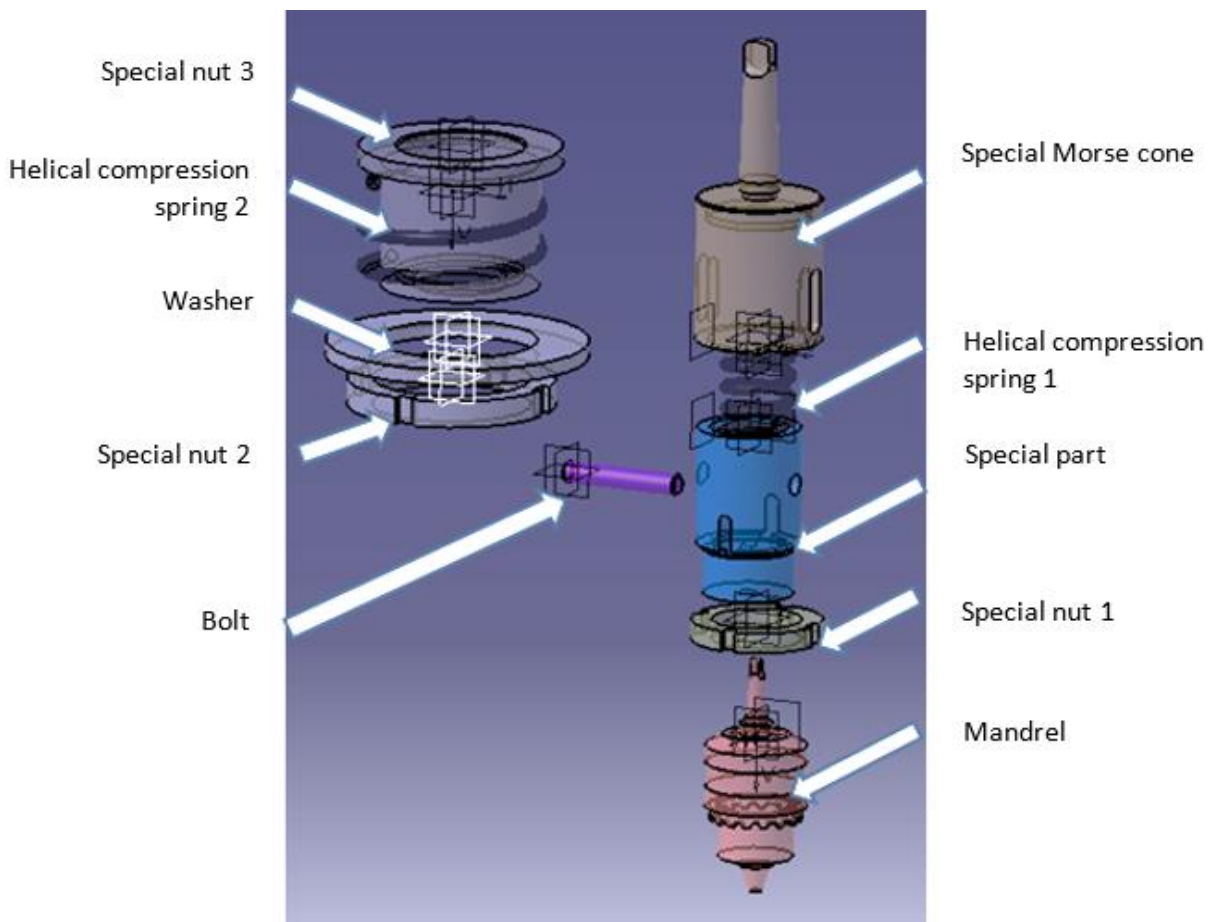

Fig. 4. Components of the device of smooth entrance in cutting

The active element of the device is the compression helical spring 1 . The compression helical spring 2 has the role of stiffening. Determining the characteristics of the compression spring 1 , the operating parameters of the device are identified.

Geometric sizes of the helical spring 1 were measured and by calculation, according to [9, 10], its characteristics were determined. The following results were obtained:

- Material: Ck67, with $\tau_{\mathrm{at}}=680 \mathrm{~N} / \mathrm{mm}^{2}$;

- Wire diameter: $\mathrm{d}=6 \mathrm{~mm}$;

- Pitch: $\mathrm{t}=10 \mathrm{~mm}$;

- External diameter: $\mathrm{D}=34 \mathrm{~mm}$;

- Average diameter: $\mathrm{D}_{\mathrm{m}}=28 \mathrm{~mm}$;

- Internal diameter: $\mathrm{D}_{1}=\mathrm{D}_{\mathrm{m}}-\mathrm{d}=22 \mathrm{~mm}$; 
- Number of coils: $n=4$;

- Number of terminating coils: $\mathrm{n}_{\mathrm{r}}=1.5$;

- The height of the spring in the free state: $\mathrm{H}_{0}=46 \mathrm{~mm}$;

- Sprig indices: $\mathrm{i}=\mathrm{D}_{\mathrm{m}} / \mathrm{d}=4.67$;

- Shape coefficient: $\mathrm{k}=1+1.6 / \mathrm{i}=1.3426$;

- $\mathrm{F}_{\max }=1534.33 \mathrm{~N}$

- Transverse modulus of elasticity: $\mathrm{G}=8 \times 10^{4} \mathrm{~N} / \mathrm{mm}^{2}$;

- Longitudinal modulus of elasticity: $\mathrm{E}=(19.5 \div 21) \times 10^{4} \mathrm{~N} / \mathrm{mm}^{2}$;

- Maximum arrow: $\mathrm{f}_{\max }=10.5 \mathrm{~mm}$;

- Minimum working height: $\mathrm{H}_{\min }=\mathrm{H}_{0}-\mathrm{f}_{\max }=35.5 \mathrm{~mm}$;

- Locking height of the spring: $\mathrm{H}_{b}=\left(n+n_{r}\right) \times d=33 \mathrm{~mm}$;

- Bow lock arrow: $\mathrm{f}_{\mathrm{b}}=\mathrm{H}_{0}-\mathrm{H}_{\mathrm{b}}=13 \mathrm{~mm}$;

- $F_{\text {pretens }}=147.28 \mathrm{~N}$;

- Spring blocking force: $\mathrm{F}_{\mathrm{b}}=\mathrm{F}_{\max } \times \mathrm{f}_{\mathrm{b}} / \mathrm{f}_{\max }=1899.65 \mathrm{~N}$.

\section{Identification of Drill Diameter Range and Cutting Parameters for C45 Steel}

In order to identify the range of diameters of the drills that can be usefully used on the device for smooth entrance in cutting, it is necessary to determine the values of the parameters of the cutting regime that influence the axial force but also to determine the values of the axial force. Values are determined in the processing of C45 steel, a steel widely used in machine building.

According to [11], at a constant diameter of the drill, the cutting feed substantially influences the axial force at drilling. As the feed values increase, the axial force values also increase. As the increase in cutting speed leads to a slight decrease in axial force, this is not included in the calculation formula.

Table 1 gives the values calculated according to [11], for the C45 steel drill, for maximum feed and axial force, when using speed steel drills in the range $1 \div 15 \mathrm{~mm}$.

Table 1. Recommended maximum feed and axial force at outside diameter and at drill core diameter when machining C45 steel

\begin{tabular}{|c|c|c|c|c|}
\hline $\begin{array}{c}\text { Diameter } \mathrm{D}_{\mathrm{b}} \\
\text { of the drill } \\
{[\mathrm{mm}]}\end{array}$ & $\begin{array}{c}\text { Recommended } \\
\text { maximum feed } \\
{[\mathrm{mm} / \mathrm{rev}]}\end{array}$ & $\begin{array}{c}\text { Axial force at } \\
\text { maximum feed } \\
{[\mathrm{N}]}\end{array}$ & $\begin{array}{c}\text { Diameter } \mathrm{d}_{0} \text { of the } \\
\text { drill core } \\
{[\mathrm{mm}]}\end{array}$ & $\begin{array}{c}\text { Axial force at diameter } \\
\mathrm{d}_{0} \text { of the drill core } \\
{[\mathrm{N}]}\end{array}$ \\
\hline 1 & 0.07 & 126.00 & 0.208 & 35.00 \\
\hline 2 & 0.10 & 297.64 & 0.362 & 71.08 \\
\hline 3 & 0.12 & 498.47 & 0.510 & 106.77 \\
\hline 4 & 0.15 & 770.12 & 0.654 & 193.35 \\
\hline 5 & 0.17 & 1040.49 & 0.797 & 235.78 \\
\hline 6 & 0.18 & 1295.31 & 0.939 & 286.29 \\
\hline 7 & 0.20 & 1550.66 & 1.080 & 340.38 \\
\hline 8 & 0.22 & 1987.14 & 1.220 & 397.93 \\
\hline 9 & 0.24 & 2385.57 & 1.359 & 446.32 \\
\hline 10 & 0.25 & 2733.54 & 1.498 & 510.05 \\
\hline 11 & 0.27 & 3180.33 & 1.636 & 562.88 \\
\hline 12 & 0.28 & 3561.67 & 1.774 & 632.55 \\
\hline 13 & 0.30 & 4053.05 & 1.911 & 689.36 \\
\hline 14 & 0.31 & 4460.39 & 2.047 & 748.00 \\
\hline 15 & 0.32 & 4882.98 & 2.183 & \\
\hline
\end{tabular}

Using the data in Table 1 and comparing with the characteristics of the spring, it is found that the smooth entrance device works optimally in the range of diameters $5 \div 8 \mathrm{~mm}$ with the feeds in the table, since at diameter $D_{b}=5 \mathrm{~mm}$ the axial force at the drill core $F_{d 0}=197.38 \mathrm{~N}>F_{\text {pretens }}=147.28 \mathrm{~N}$ and at the diameter of $8 \mathrm{~mm}$ the axial force $\mathrm{F}_{\mathrm{x}}=1987.14 \mathrm{~N}$ at cutting is almost equal with the the blocking force of the spring $\mathrm{F}_{\mathrm{b}}=1899.65 \mathrm{~N}$. 


\section{Widening the Range of Diameters for the Smooth Entrance in Cutting Device}

To widen the diameter range of the drill used on the smooth entrance in cutting device, a spring is designed, concentric with the original spring of the device, and which enters inside it. The new spring can work alone or together with the original spring.

The calculation and characteristics of the new spring are shown below:

- Sprin material: Ck67 with $\tau_{\mathrm{at}}=680 \mathrm{~N} / \mathrm{mm}^{2}$;

- Free height of the spring: $\mathrm{H}_{0}=46 \mathrm{~mm}$;

- Wire diameter: $\mathrm{d}=3.6 \mathrm{~mm}$;

- Number of coils: $\mathrm{n}=7$;

- Number of terminating coils: $\mathrm{n}_{\mathrm{r}}=1.5$;

- Pitch: $\mathrm{t}=\left[\mathrm{H}_{\mathrm{o}}-\left(\mathrm{n}_{\mathrm{r}}-0.5\right) \times \mathrm{d}\right] / \mathrm{n}=6.057 \mathrm{~mm}$;

- $\mathrm{D}=20.4 \mathrm{~mm} ; \mathrm{D}_{\mathrm{m}}=16.8 \mathrm{~mm} ; \mathrm{D}_{\mathrm{i}}=13.2 \mathrm{~mm}$;

- $\quad \mathrm{i}=\mathrm{D}_{\mathrm{m}} / \mathrm{d}=4.67 ; \mathrm{k}=1+1.6 / \mathrm{d}=1.44$;

- $\mathrm{F}_{\max }=515 \mathrm{~N}$;

- $\mathrm{f}_{\max }=10.2 \mathrm{~mm}$;

- $\mathrm{H}_{\min }=\mathrm{H}_{0}-\mathrm{f}_{\max }=35.8 \mathrm{~mm}$;

- $\mathrm{H}_{\mathrm{b}}$ (blocking height $)=\left(\mathrm{n}+\mathrm{n}_{\mathrm{r}}\right) \times \mathrm{d}=30.6 \mathrm{~mm}$;

- $\mathrm{f}_{\mathrm{b}}$ (blocking arrow) $=\mathrm{H}_{0}-\mathrm{H}_{\mathrm{b}}=15.4 \mathrm{~mm}$;

- $F_{b}$ (blocking force) $=F_{\max } \times f_{b} / f_{\max }=777.55 \mathrm{~N}$;

- $\mathrm{F}_{\text {pretens }}=50.5 \mathrm{~N}$.

Comparing the characteristics of the spring with the data in Table 1 it is found that at the diameter $\mathrm{D}_{\mathrm{b}}=2 \mathrm{~mm}$ the cutting force at the drill core $\mathrm{F}_{\mathrm{d} 0}=71.08 \mathrm{~N}>\mathrm{F}_{\text {pretens }}=50.5 \mathrm{~N}$ and at the diameter of $4 \mathrm{~mm}$ the axial force $F_{x}=770.12 \mathrm{~N}$ is almost equal with the spring blocking force $F_{b}=777.55 \mathrm{~N}$.

If the springs work at the same time (work in parallel) the following characteristics result:

- $\mathrm{F}_{\text {pretens }}=\mathrm{F}_{\text {pretens } 1}+\mathrm{F}_{\text {pretens } 2}=197.28 \mathrm{~N}$;

- $\mathrm{F}_{\max }=\mathrm{F}_{\max 1}+\mathrm{F}_{\max 2}=2049.33 \mathrm{~N}$;

- $\mathrm{F}_{\mathrm{b}}=\mathrm{F}_{\mathrm{b} 1}+\mathrm{F}_{\mathrm{b} 2}=2677.2 \mathrm{~N}$.

In this case the range of diameters for which the device can be used is between $5 \div 10 \mathrm{~mm}$.

For a better comparison of the two springs their characteristics are presented, comparatively, in Table 2.

Table 2. The main characteristics of the springs resulting from the reengineering of the device

\begin{tabular}{|ll|c|c|}
\hline \multicolumn{2}{|c|}{ Parameter } & Spring 1 & Spring 2 \\
\hline External diameter & $\mathrm{D}[\mathrm{mm}]$ & 20.4 & 34 \\
\hline Internal diameter & $\mathrm{D}_{\mathrm{i}}[\mathrm{mm}]$ & 13.2 & 22 \\
\hline Wire diameter & $\mathrm{d}[\mathrm{mm}]$ & 3.6 & 6 \\
\hline Free height & $\mathrm{H}_{0}[\mathrm{~mm}]$ & 46 & 46 \\
\hline Blocking height & $\mathrm{H}_{\mathrm{b}}[\mathrm{mm}]$ & 30.6 & 33 \\
\hline Working minimum height & $\mathrm{H}_{\min }[\mathrm{mm}]$ & 35.8 & 35.5 \\
\hline Pretension force & $\mathrm{F}_{\text {pretens }}[\mathrm{N}]$ & 50.5 & 147.28 \\
\hline Maximum force & $\mathrm{F}_{\max }[\mathrm{N}]$ & 515 & 1534.33 \\
\hline Blocking force & $\mathrm{F}_{\mathrm{b}}[\mathrm{N}]$ & 777.55 & 1899.65 \\
\hline
\end{tabular}

From Table 2 it can be seen that the free height of the springs, the minimum working height and the blocking height are almost identical which makes the springs work very well in parallel (concentric).

\section{Conclusions}

Based on the information presented in the paper, the following conclusions can be drawn:

- the smooth entrance of the drill in the cutting leads to the increase of the durability of the tool [5];

- this paper continues the research [5] by analyzing and improving the smooth entry device in the cutting; 
- identify the requirements for the device to work effectively; these are: the force at the diameter of the drill core must be greater than the prestressing force of the spring and the maximum cutting force must be less than the blocking force of the helical spring;

- the range of drill diameters that can be used efficiently on the current device is identified, for the C45 steel drill, this being $5 \div 8 \mathrm{~mm}$; for this purpose, the maximum machining feed was determined and the axial force at the maximum feed was calculated;

- using reengineering elements, the range for using of the smooth entrance in cutting device is increased by inserting a second, smaller spring, which is inserted inside the first helical spring;

- the second spring is dimensioned in such a way as to work in parallel with the first spring;

- the working method for C45 steel is the following: for a drill diameter in the range $2 \div 4 \mathrm{~mm}$ the smaller spring is used; for the diameter of the drill in the range $5 \div 8 \mathrm{~mm}$ the larger spring is used and for the diameter of the drill in the range $9 \div 10 \mathrm{~mm}$ the first spring is inserted inside the second spring and they will work in parallel;

- if a material other than C45 is processed, the axial force must be determined and based on Table 2 the new range of diameters of the drills will be indicated.

\section{References}

1. Ștețiu Gr., Lăzărescu I., Oprean C., Ștețiu M. (1994): Teoria și practica sculelor așchietoare (Theory and practice of cutting tools). Vol. I, University of Sibiu Publishing house, ISBN 973-95604-3-1, Romania (in Romanian)

2. Cordebois J.-P., et al. (2003): Fabrication par usinage (Machining manufacturing). Dunod, ISBN 978-2-10005586-9, Paris, France (in French)

3. Dițu V. (2008): Bazele așchierii metalelor. Teorie și aplicații (Fundamentals of cutting metals. Theory and applications). MatrixRom, ISBN 978-973-755-444-4, București, Romania (in Romanian)

4. Fetecău C. (2001): Relații parametrice utilizate la așchiere (Parametric relations when cutting). Editura Tehnică, ISBN 973-31-2020-0, București, Romania (in Romanian)

5. Diţu V., Oancea Gh., Daicu R. (2016): Researches on evaluation of smooth entrance in cutting using electrical current. A case study. MATEC Web Conf., Vol. 94, https://doi.org/10.1051/matecconf/20179402005

6. Daicu R., Dițu V., Oancea Gh. (2017): Innovative approach of drills acquisition using electrical current. A case study. MATEC Web Conf., Vol. 112, https://doi.org/10.1051/matecconf/201711201023

7. Capasso S., Paiva J.M. et al. (2019): A novel method of assessing and predicting coated cutting tool wear during Inconel DA 718 turning. Wear, ISSN 0043-1648, Vol. 432-433, https://doi.org/10.1016/j.wear.2019.202949

8. Maruda W.R., Krolczyk G.M. et al. (2017): Tool wear characterizations in finish turning of AISI 1045 carbon steel for MQCL conditions. Wear, ISSN 0043-1648, Vol. 372-373, https://doi.org/10.1016/i.wear.2016.12.006

9. https://kupdf.net/download/arcuri-calculul-arcurilor_5912f55edc0d60167d959e85_pdf

10. Chişiu A. ş.a. (1976): Organe de maşini (Machine parts). Didactic and Pedagogical Publishing House, București, România (in Romanian)

11. Picoș C., et al. (1992): Proiectarea tehnologiilor de prelucrare mecanică prin așchiere (Design of mechanical machining technologies). Universitas Publishing house, ISBN 5-362-00971-0, Chișinău, Republic of Moldova 